\title{
Acute pancreatitis and upper gastrointestinal bleeding as presenting symptoms of a duodenal Brunner's gland hamartoma
}

\author{
Edy Stermer $M D^{1}$, Nizar Elias $M D^{2}$, Dean Keren $M D^{1}$, Tova Rainis $M D^{1}$, Omer Goldstein $M D^{1}$, Alexandra Lavy MD
}

\begin{abstract}
E Stermer, N Elias, D Keren, T Rainis, O Goldstein, A Lavy. Acute pancreatitis and upper gastrointestinal bleeding as presenting symptoms of a duodenal Brunner's gland hamartoma. Can J Gastroenterol 2006;20(8):541-542.

Brunner's gland hamartomas are rare, benign small bowel tumours. There were fewer than 150 cases reported in the English literature until the end of the last century. These hamartomas may be discovered incidentally during an upper gastrointestinal tract endoscopy. Otherwise, they may be diagnosed in patients presenting with acute upper gastrointestinal bleeding, anemia or symptoms of intestinal obstruction. The case of a young woman admitted for acute upper gastrointestinal bleeding along with acute pancreatitis is presented. The investigation revealed a giant Brunner's gland hamartoma in the second part of the duodenum. After total endoscopic resection of the tumour, the patient has remained completely asymptomatic for a follow-up period of seven months.
\end{abstract}

Key Words: Acute pancreatitis; Brunner's gland; Gastrointestinal bleeding; Hamartoma

Rrunner's gland hamartomas are rare, benign tumours, most Boften located in the duodenum, usually at the bulb or second part. They may be discovered incidentally, or may be the cause of gastrointestinal bleeding, iron deficiency anemia or upper gastrointestinal obstructive symptoms.

\section{CASE PRESENTATION}

A 20-year-old woman was admitted to the Department of Medicine, Bnai Zion Medical Center, Haifa, Israel, for abdominal pain and melena that began three days before admission.

The pain was severe, localized to the upper abdomen, persistent and noncolicky. On admission to the medical ward, she was alert and well nourished, without scleral icterus or lymphadenopathy. She had no personal or family history of gastrointestinal disease, and there was no history of alcohol use.

On examination, the abdomen was soft but tender in the periumbilical area, without peritoneal irritation. Rectal examination showed traces of melena. Routine laboratory examinations showed a hemoglobin level of $115 \mathrm{~g} / \mathrm{L}$, a leukocyte concentration of $9.9 \times 10^{9} / \mathrm{L}$, and normal serum levels of urea, glucose, bilirubin, aspartate aminotransferase, alkaline phosphatase, electrolytes, serum cholesterol and triglycerides. The serum amylase level was $1054 \mathrm{U} / \mathrm{L}$ (normal range $30 \mathrm{U} / \mathrm{L}$ to

\section{Une pancréatite aiguë est des saignements gastro-œso-dudonénaux comme manifestations initiales d'un hamartome des glandes de Brunner}

\begin{abstract}
Les hamartomes des glandes de Brunner sont des tumeurs rares et bénignes de l'intestin grêle. À la fin du siècle dernier, moins de 150 cas avaient été déclarés dans les publications anglophones. Il se peut que ces hamartomes soient découverts par hasard pendant une endoscopie du transit gastro-œeso-duodénal. Autrement, ils peuvent être diagnostiqués chez des patients qui souffrent d'hémorragies gastro-œeso-duodénales, d'anémie ou de symptômes d'occlusion intestinale. Le cas d'une jeune femme hospitalisée en raison d'hémorragies gastro-œeso-duodénales et d'une pancréatite aiguë est présenté. L'exploration a révélé la présence d'un hamartome géant des glandes de Brunner dans la deuxième partie du duodénum. Après une résection endoscopique totale de la tumeur, la patiente est demeurée complètement asymptomatique pendant une période de suivi de sept mois.
\end{abstract}

$100 \mathrm{U} / \mathrm{L}$ ) and the urinary amylase level was $5220 \mathrm{U} / \mathrm{L}$ (normal range $20 \mathrm{U} / \mathrm{L}$ to $500 \mathrm{U} / \mathrm{L}$ ). The chest and abdominal $\mathrm{x}$-rays were unremarkable.

The abdominal ultrasonography was normal; a subsequent computed tomography scan disclosed a slightly edematous pancreas, with normal bile ducts and liver. A large $(5 \mathrm{~cm})$ filling defect with soft borders was revealed in the second part of the duodenum, partially obstructing the lumen (Figure 1). Gastroscopy showed a $7 \mathrm{~cm}$ long, lobulated mass with an ulcerated surface, freely moving on a long pedicle in the proximity of the papilla Vateri (Figure 2).

Treatment with omeprazole and analgesics resulted in the resolution of abdominal pain four days after admission. The polypoid mass was dragged into the stomach, and a one-stage endoscopic polypectomy was performed using $40 \mathrm{~W}$ of coagulation current. Within five days, the amylase levels progressively decreased to normal. The hemoglobin levels remained stable. On histological examination, the polyp was formed by nondysplastic, lobulated Brunner's glands, with intervening bands of fibrous tissue, adipose cells and lymphoid cells (Figure 3).

On follow-up visits three and seven months after discharge, the patient remained asymptomatic. Her most recent hemoglobin level was $127 \mathrm{~g} / \mathrm{L}$ and the diastase level was normal. A fecal occult blood test examination was negative.

Departments of ${ }^{1}$ Gastroenterology and ${ }^{2}$ Internal Medicine, Bnai Zion Medical Center, The Bruce Rappaport School of Medicine, Technion, Haifa, Israel

Correspondence: Dr Edy Stermer, Bnai Zion Medical Center, PO Box 4940, Haifa 31048, Israel. Telephone 972-4-8359426,

fax972-4-8359726,e-mail edystermer@yahoo.com or edy.stermer@b-zion.org.il

Received for publication November 9, 2005. Accepted December 16, 2005 


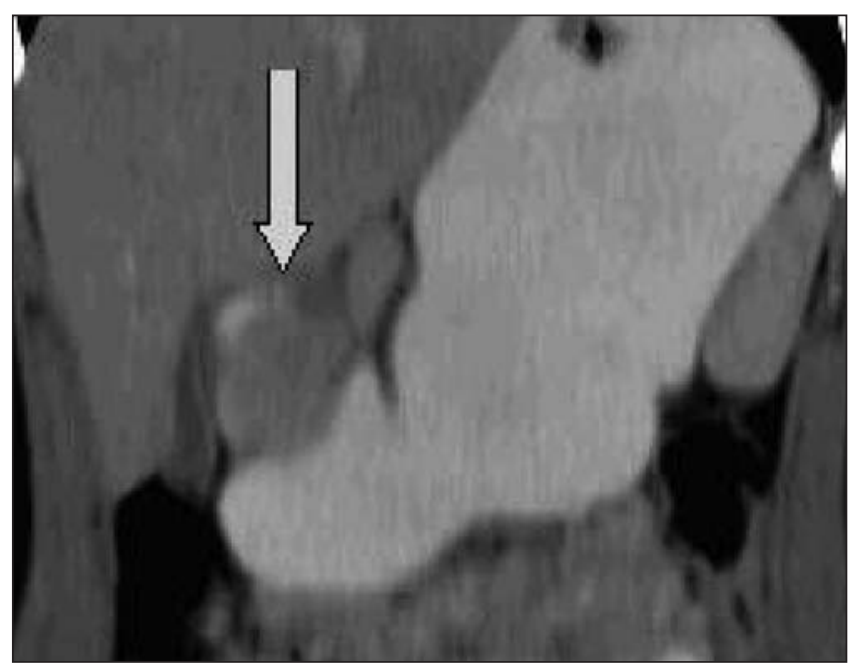

Figure 1) Abdominal computed tomography scan showing the large duodenal polyp

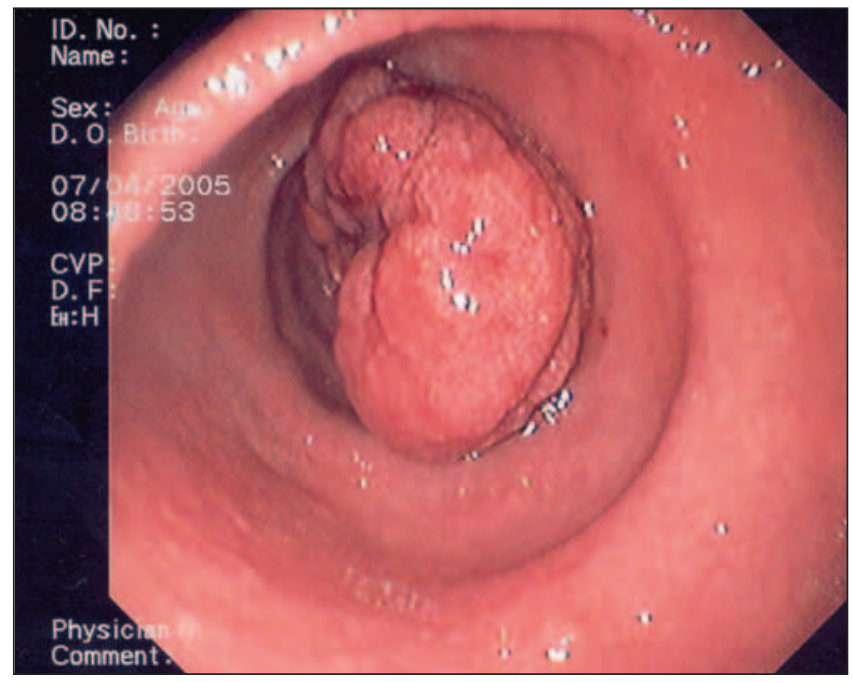

Figure 2) Endoscopic view of the large duodenal polyp

\section{DISCUSSION}

Duodenal tumours are infrequent findings, while Brunner's cell tumours are even less frequently diagnosed. Brunner's glands are found at the gastrointestinal junction and extend for variable distances distally in the wall of the proximal small intestine. The secretory units of Brunner's glands consist of epithelial tubules that show frequent distal branchings. They produce mucin glycoproteins, limited amounts of bicarbonate, epidermal growth factor, bactericidal factors and proteinase inhibitors. All these products contribute to the mucosal surface protection. Brunner's gland hamartomas were first described by Cruveilhier in 1835 (1) in a patient with fatal duodenal intussusception. These tumours are usually located in the duodenal bulb or in the second duodenal portion. They are benign small bowel tumours, with fewer than 150 cases reported in the English literature until the end of the last century (2); they represented $13 \%$ of a large, Australian series of benign small bowel tumours (3). Brunner's gland hamartomas are more commonly discovered during an episode of acute upper gastrointestinal bleeding (4-6), in evaluating the cause of iron deficiency anemia (7) or because of gastrointestinal obstructive symptoms $(8,9)$. Unusual among the presentations of

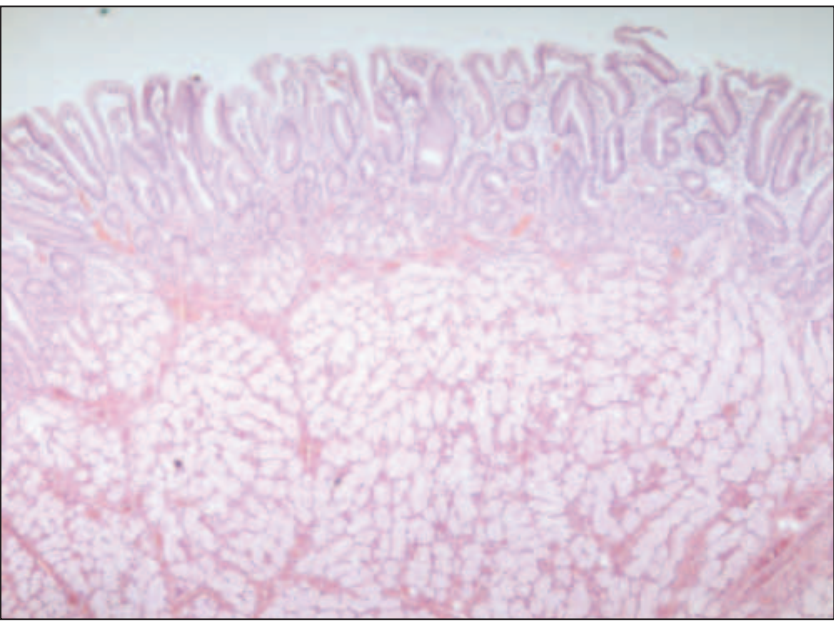

Figure 3) Biopsy from the duodenal polyp. Hematoxylin and eosin stain, original magnification $\times 25$

Brunner's gland hamartoma is a biliary fistula (10) as an imitator of carcinoma of the head of pancreas (11) or causing pancreatitis (12). The presenting symptom in our patient was acute upper gastrointestinal bleeding, which is a common presentation of this tumour. However, she also had severe abdominal pain and hyperamylasemia, consistent with acute pancreatitis. The association of upper intestinal bleeding and hyperamylasemia in the presence of a juxtapapillary mass is suggestive of obstruction of the papilla Vateri by the duodenal mass. The remission of symptoms after ablation of the duodenal tumour and the return to normal of the laboratory abnormalities may attest that the intestinal bleeding and pancreatitis were both caused by the duodenal mass. Furthermore, the patient has remained completely asymptomatic after seven months of follow-up. There was no ongoing anemia; her most recent hemoglobin level was $127 \mathrm{~g} / \mathrm{L}$ and the diastase level was normal. In reviewing the literature, we could not find any other report of Brunner's cell duodenal hamartoma presenting with both intestinal bleeding and pancreatitis.

\section{REFERENCES}

1. Cruveilhier J. Anatomie pathologique du corps humain. Paris: JB Balliere, 1835.

2. Chen TM, Changchien CS, Hsu CC, Hu Th. Brunner's gland hamartomas: Report of three cases. Changgeng Yi Xue Za Zhi 1999;22:271-6.

3. Rangiah DS, Cox M, Richardson M, Tompsett E, Crawford M. Small bowel tumours: A 10 year experience in four Sidney teaching hospitals. ANZ J Surg 2004;74:788-92

4. Levine JA, Burgart LJ, Batts KP, Wang KK. Brunner's gland hamartomas: Clinical presentation and pathological features of 27 cases. Am J Gastroenterol 1995;90:290-4

5. Schluger LK, Rotterdam H, Lebwohl O. Gastrointestinal hemorrhage from Brunner's gland hamartoma. Am J Gastroenterol 1994;89:2088-9.

6. Stolpman DR, Hunt GC, Sheppard B, Huang H, Gopal DV. Brunner's gland hamartoma: A rare cause of gastrointestinal bleeding - Case report and review of the literature. Can J Gastroenterol 2002;16:309-13.

7. Zangara J, Kushner H, Drachenberg C, Daly B, Flowers J, Fantry G. Iron deficiency anemia due to a Brunner's gland hamartoma. J Clin Gastroenterol 1998;27:353-6.

8. Lingawi SS, Filipenko JD. Brunner's gland hamartoma causing gastric outlet obstructive symptoms. South Med J 1998;91:964-5.

9. Gockel I, Oberholzer K, Seifert JK, Junginger T. Hamartoma of the duodenum. Dtsch Med Wochenschr 2005;130:1637-40.

10. Hedges AR. Hamartoma of Brunner's gland causing pyloric obstruction and a biliary fistula. Case report. Acta Chir Scand 1988;154:475-6.

11. Skellenger ME, Kinner BM, Jordan PH Jr. Brunner's gland hamartomas can mimic carcinoma of the head of the pancreas. Surg Gynecol Obstet 1983;156:744-6.

12. Scholz HG. Recurrent acute pancreatitis, a complication of brunneromas Leber Magen Darm 1976;6:300-2. 


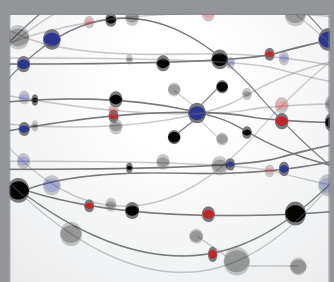

The Scientific World Journal
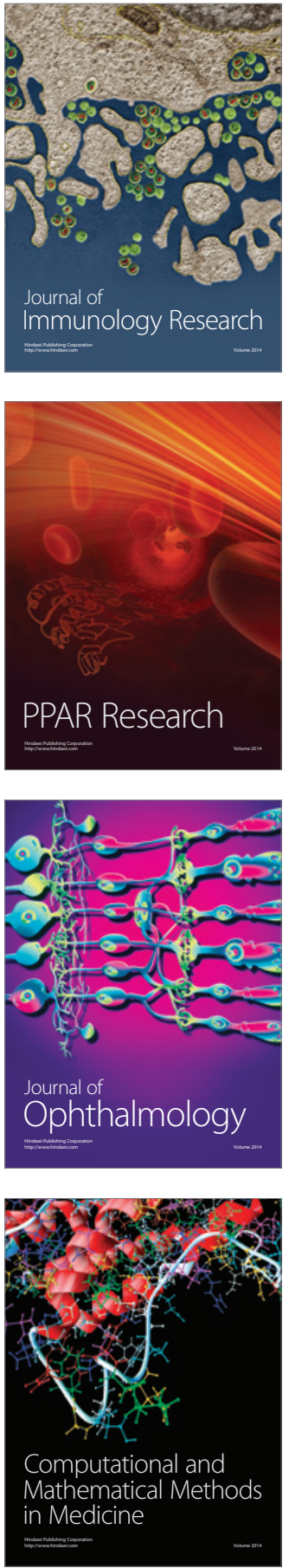

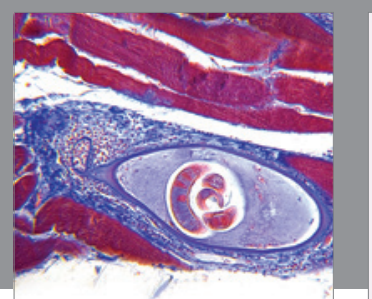

Gastroenterology Research and Practice

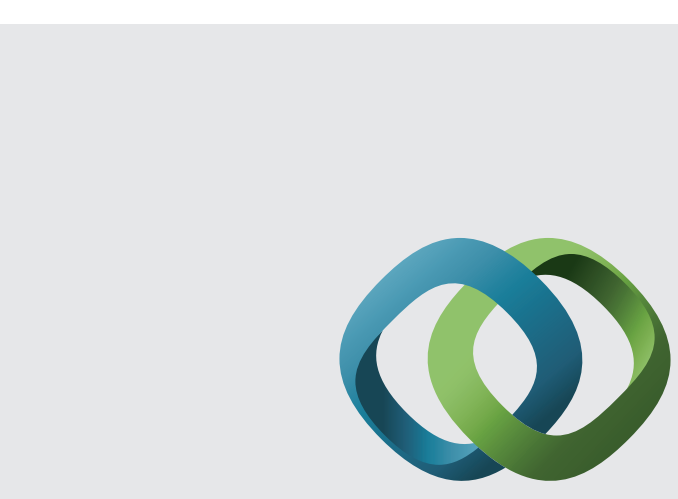

\section{Hindawi}

Submit your manuscripts at

http://www.hindawi.com
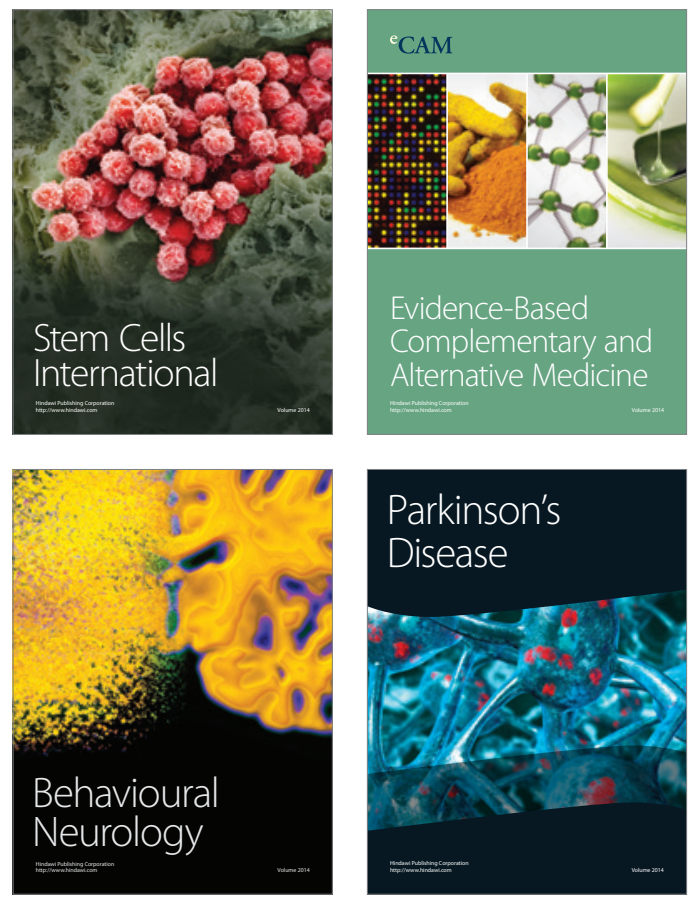
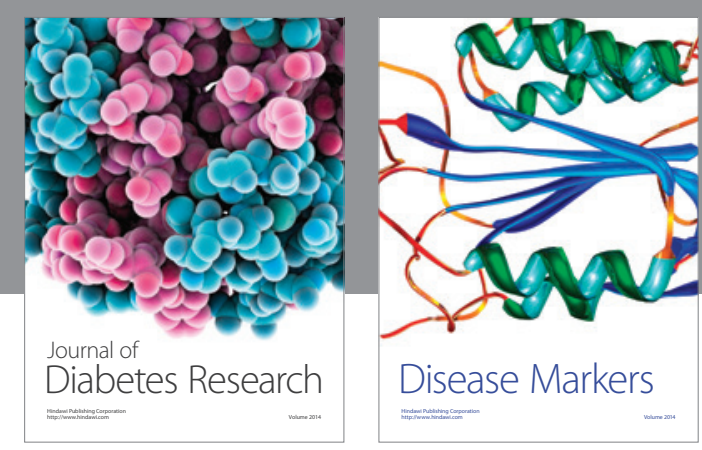

Disease Markers
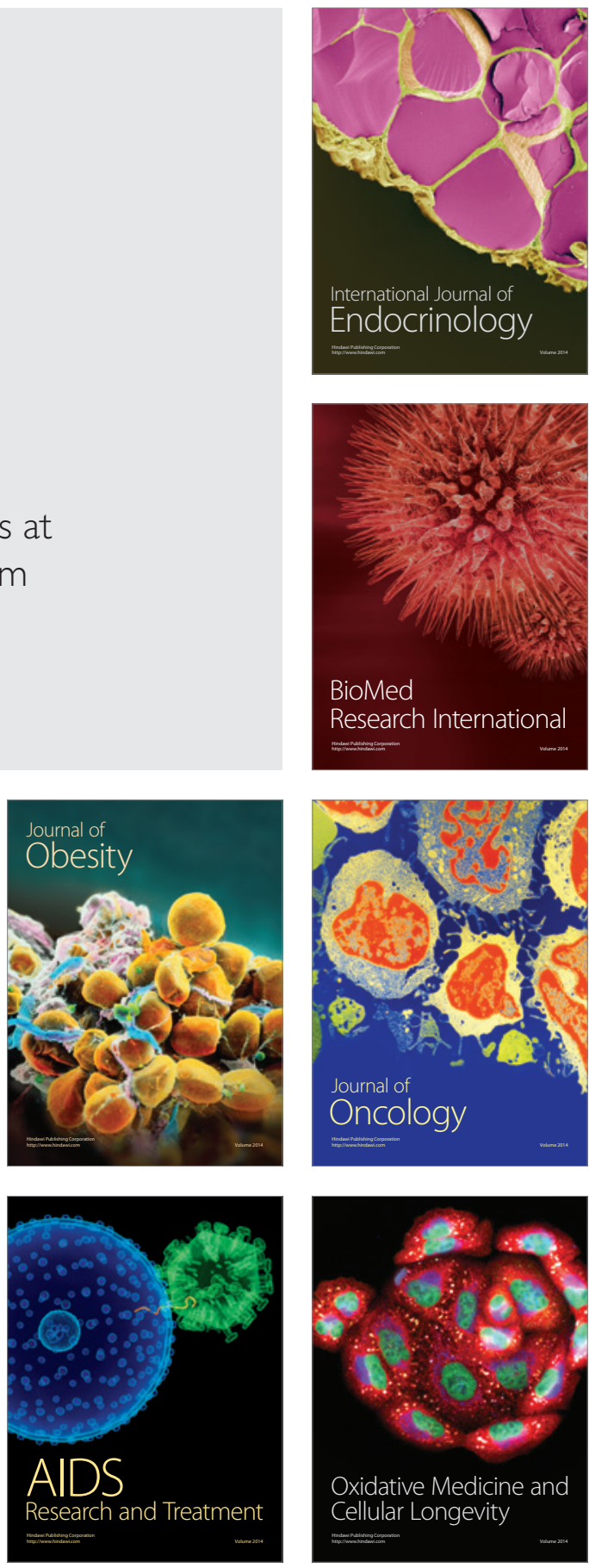